\title{
A Study on Service Quality in Banks with Special Reference to SIB Customers of Thrissur Town, Kerala
}

\author{
K. R. Mary Liya \\ Assistant professor, Vimala College, Kerala, India \\ E-Mail: maryliyakr@gmail.com
}

\begin{abstract}
In the era of privatization, liberalization and globalization banks play a dynamic role in contributing to the economic development of the country the banking industry in India facing certain challenges that are challenge of quality service, customer satisfaction, customer retention, customer loyalty. Quality service plays a major role in achieving customer satisfaction and creating brand loyalty in banking sector. Service quality is also interrelated to other behavioral outcome of the customers. Study understands the various customer perceptions about service quality factors like assurance, empathy, responsiveness, reliability, and tangibility in banking industry and the satisfaction level towards the banks as service quality reflects the way the banks are performing the present study attempts to explore the perception and expectation of customers in respect to the services provided by banks.

Keywords: Reliability, Responsiveness, Assurance, Empathy, Tangibles
\end{abstract}

\section{INTRODUCTION}

The advanced economies and advancing economies of the world are now dominated by services, and virtually all companies view service as critical to retaining their customers today and in future. Even manufacturing companies that in the past have depended on their physical products for their livelihood now recognize that service provides one of their few sustainable competitive advantages. The development of strong customer relationship through quality service is important and applicable to organizations whose core product is service and to organizations that depend on service excellence for competitive advantage.

Many firms has made investments to promote service quality, based on faith and intuition by managers who believed in serving customers well and who believed in their hearts that quality service made good business sense. Indeed, a dedication to quality service has been the foundation for success for many firms, across industries. Services are heterogeneous and intangible in nature the services vary from one bank to another and only continuous learning and updating organization can survive in this competitive world. Increased competition, highly educated consumers and increase in standard of living of people are forcing many businesses to review their customer service strategy. It means higher the service quality, higher the customer satisfaction.

\section{OBJECTIVES OF THE STUDY}

1. To analyze the level of awareness of customers towards banking services.

2. To understand the satisfaction of customers towards banking services.

3. To analyze the perception of customers towards quality services.

\section{METHODOLOGY}

Both primary and secondary source were used for collecting data. For getting primary data questionnaire method is used. Secondary data is collected from journals and magazines. The Present study is descriptive in nature because it aims to analyze the awareness and satisfaction of customers towards banking services. It also helps to understand the perception and expectation of customers towards quality services. This study is conducted among the SIB customers of Thrissur town. 120 respondents were identified on the basis of convenience sampling method and further their accessibility and availability was also taken into consideration.

\section{A. Hypothesis}

$H_{1}$ : The opinion towards dimensions of service quality are equal to average.

\section{FINDINGS OF THE STUDY}

The major findings of the study which is related to the Awareness, Satisfaction, Tangibility, Reliability, Responsiveness, Assurance and Empathy dimensions of customers related to banking services are presented in the following paragraphs.

\section{A. Awareness of Customers towards Banking Services}

$H_{0}$ : Opinion Of People towards the Statements of Awareness about Banking Services Is equal to Average.

Table I shows the statements regarding awareness about banking services. Since p value is less than 0.01 , in null hypothesis is rejected at $1 \%$ level of significance with regard to the statements AS1, AS3, AS4, AS5, AS6, AS7, AS8. Hence the opinion towards the statements is not equal to average. Statement AS10 is rejected @5\%level as the p 
value is less than 0.05 . Hence concluded that opinion towards these statements is not equal to average. Based on the mean score, people shows agreeability towards the statement as mean value is above average. Since $p$ value is greater than 0.05, H0 is accepted @5\% level with regard to A2 \&A9. Hence concluded that opinion towards the statements is equal to average.

TABLE I T TEST BASEd ON AWARENESS ABOUt SERVICES

\begin{tabular}{|l|c|c|c|c|}
\hline \multicolumn{1}{|c|}{$\begin{array}{c}\text { AS: awareness about } \\
\text { banking services }\end{array}$} & Mean & $\begin{array}{c}\text { Std. } \\
\text { Deviation }\end{array}$ & $\begin{array}{c}\text { T } \\
\text { value }\end{array}$ & $\begin{array}{c}\text { P } \\
\text { value }\end{array}$ \\
\hline AS1: current account & 3.83 & 0.911 & 10.025 & $<0.001$ \\
\hline AS2 :mercantile credit & 3.18 & 0.967 & 1.982 & 0.051 \\
\hline AS3: money transfer & 3.99 & 0.912 & 11.911 & $<0.001$ \\
\hline AS4: any branch banking & 3.65 & 1.010 & 7.053 & $<0.001$ \\
\hline AS5: e-banking & 4.08 & 0.989 & 11.911 & $<0.001$ \\
\hline AS6: cell phone banking & 3.88 & 1.014 & 9.542 & $<0.001$ \\
\hline AS7: NRI-banking & 3.68 & 1.137 & 6.581 & $<0.001$ \\
\hline AS8: ATM & 4.68 & 0.518 & 35.578 & $<0.001$ \\
\hline AS9: demat services & 3.02 & 1.021 & 0.179 & 0.858 \\
\hline $\begin{array}{l}\text { AS10: general insurance\& } \\
\text { life insurance }\end{array}$ & 3.25 & 1.063 & 2.576 & 0.011 \\
\hline
\end{tabular}

\section{B. Satisfaction of Customers towards Banking Services}

$H_{0}$ : Opinion Of People Towards The Statements Of Satisfaction Towards Banking Services Is Equal To Average.

Table II shows the statements regarding satisfaction towards banking services. Since p value in table 1.2 is less than 0.01 in the case of SS1, SS2, SS3, SS4, SS5, SS6, SS7, SS8, SS9 null hypothesis is rejected at $1 \%$ level of significance. In case of SS10 the null hypothesis is accepted at 5\% level of significance. Based on the mean score of the opinion regarding all the statement of relation with satisfaction SS1, SS3, SS4, SS5, SS6, SS7, SS8 are above average level and SS2, SS9, SS10 are below average level.

TABle II The T Test Based On The SATisfaction TOWARDS SERVices

\begin{tabular}{|l|c|c|c|c|}
\hline SS : Satisfaction towards banking services & Mean & Std. Deviation & T value & P value \\
\hline SS1 : current account & 3.38 & 1.006 & 4.175 & $<0.001$ \\
\hline SS2 : mercantile credit & 2.66 & 1.192 & -3.141 & $<0.001$ \\
\hline SS3 : money transfer & 3.63 & 0.988 & 6.931 & $<0.001$ \\
\hline SS4 : any branch banking & 3.52 & 1.077 & 5.256 & $<0.001$ \\
\hline SS5 : e- banking & 3.68 & 1.237 & 6.053 & $<0.001$ \\
\hline SS6 : cell phone banking & 3.67 & 1.125 & 6.490 & $<0.001$ \\
\hline SS7 : NRI-banking & 3.32 & 1.316 & 2.637 & $<0.001$ \\
\hline SS8 : ATM & 4.59 & 0.642 & 27.174 & $<0.001$ \\
\hline SS9 : demat services & 2.65 & 1.186 & -3.234 & $<0.001$ \\
\hline SS10 : general insurance \& life insurance & 2.92 & 1.220 & -0.748 & 0.456 \\
\hline
\end{tabular}

\section{Tangibility Dimension of Service Quality}

$H_{0}$ : The Opinion Of People Towards The Statements Of Tangibility Dimension Is Equal To Average.

Since p value is less than 0.01 in all case the null hypothesis is rejected at $1 \%$ level of significance. Hence it can be concluded that opinion regarding all the statements of tangibility dimension are not equal to average level. Based on the mean score the statements are above average level, which shows agreeability towards these statements.

\section{Reliability Dimension of Service Quality}

$H_{0}$ : The Opinion Of People Towards The Statements Of Reliability Dimension Is Equal To Average.

Since $\mathrm{p}$ value is less than 0.01 in all case, the null hypothesis is rejected at $1 \%$ level of significance. Hence it can be concluded that opinion regarding all the statements of reliability are not equal to average level. Based on the mean score all the statements are above average level, which shows agreeability towards these statements. 
TABLe III Shows The TANGIBILITY Dimension Of SERVICE Quality

\begin{tabular}{|l|c|c|c|c|}
\hline \multicolumn{1}{|c|}{ TANG: Tangibility } & Mean & Std. Deviation & T value & P value \\
\hline $\begin{array}{l}\text { TANG_1 : The bank has modern looking } \\
\text { equipment }\end{array}$ & 4.20 & 0.574 & 22.904 & $<0.001$ \\
\hline $\begin{array}{l}\text { TANG_2 : The bank's physical features are } \\
\text { visually appealing }\end{array}$ & 4.20 & 0.588 & 22.341 & $<0.001$ \\
\hline $\begin{array}{l}\text { TANG_3 : The bank's reception desk } \\
\text { employees are neat in appearing }\end{array}$ & 4.22 & 0.624 & 21.352 & $<0.001$ \\
\hline $\begin{array}{l}\text { TANG_4: Materials associated with the services } \\
\text { are visually }\end{array}$ & 3.97 & 0.634 & 16.696 & $<0.001$ \\
\hline
\end{tabular}

\section{E. Responsiveness Dimension of Service Quality}

$H_{0}$ : The Opinion of People towards the Statements of Responsiveness Dimension Is Equal to Average

Since $\mathrm{p}$ value is less than 0.01 in all case, the null hypothesis is rejected at $1 \%$ level of significance. Hence it can be concluded that opinion regarding all the statements of reliability are not equal to average level. Based on the mean score of the opinion regarding all the statements are above average level, which shows agreeability towards the statements.

TABLE IV ShOWs The Reliability Dimension Of SERVICE QuAlity

\begin{tabular}{|l|c|c|c|c|}
\hline \multicolumn{1}{|c|}{ REL : Reliability } & Mean & Std. Deviation & T value & P value \\
\hline $\begin{array}{l}\text { REL_1 : When the bank promise to do something by a } \\
\text { certain time it does so }\end{array}$ & 3.81 & 0.823 & 10.760 & $<0.001$ \\
\hline $\begin{array}{l}\text { REL_2 : When I have a problem the bank shows a } \\
\text { sincere interest in solving it }\end{array}$ & 3.72 & 0.891 & 8.816 & $<0.001$ \\
\hline $\begin{array}{l}\text { REL_3 : The bank performs the service right the first } \\
\text { time }\end{array}$ & 3.55 & 0.818 & 7.362 & $<0.001$ \\
\hline $\begin{array}{l}\text { REL_4 : The bank provide it's services at the time it } \\
\text { promise to do so. }\end{array}$ & 3.84 & 0.722 & 12.774 & $<0.001$ \\
\hline REL_5 :The bank need to insist on error free records & 3.59 & 0.761 & 8.512 & $<0.001$ \\
\hline
\end{tabular}

TAble V Shows The Responsiveness Dimension Of SERVICE Quality

\begin{tabular}{|l|c|c|c|c|}
\hline \multicolumn{1}{|c|}{ RES : Responsiveness } & Mean & Std. Deviation & T value & P value \\
\hline $\begin{array}{l}\text { RES_1 : Employees in the bank should tell me exactly } \\
\text { when the service will be performed }\end{array}$ & 3.77 & 0.796 & 10.546 & $<0.001$ \\
\hline $\begin{array}{l}\text { RES_2 : Employees in the bank should give me prompt } \\
\text { service }\end{array}$ & 3.99 & 0.761 & 14.267 & $<0.001$ \\
\hline $\begin{array}{l}\text { RES_3 : Employees in the bank are should be always } \\
\text { willing to help me }\end{array}$ & 3.93 & 0.724 & 14.002 & $<0.001$ \\
\hline $\begin{array}{l}\text { RES_4 : Employees in the bank are never too busy to } \\
\text { respond to your request }\end{array}$ & 3.74 & 0.750 & 10.828 & $<0.001$ \\
\hline
\end{tabular}

\section{F. Assurance Dimension of Service Quality}

$H_{0}$ : The Opinion Of People Towards The Statements Of Assurance Dimension Is Equal To Average.

Since $\mathrm{p}$ value is less than 0.01 in all case, the null hypothesis is rejected at $1 \%$ level of significance. Hence it can be concluded that opinion regarding all the statements of reliability are not equal to average level. Based on the mean score of the opinion regarding all the statements are above average level, which shows agreeability towards the statements.

\section{G. Empathy Dimension of Service Quality}

$H_{0}$ : The opinion of people towards the statements of empathy dimension is equal to average.

Since $\mathrm{p}$ value is less than 0.01 in all case, the null hypothesis is rejected at $1 \%$ level of significance. Hence it can be concluded that opinion regarding all the statements of reliability are not equal to average level. Based on the mean score of the opinion regarding all the statements are above average level, which shows agreeability towards the statements. 
Table VI Shows The Assurance Dimension Of Service Quality

\begin{tabular}{|l|c|c|c|c|}
\hline \multicolumn{1}{|c|}{ ASS : Assurance } & Mean & Std. Deviation & T value & P value \\
\hline $\begin{array}{l}\text { ASS_1 : The behaviour of employees in the bank } \\
\text { instills confidence in me }\end{array}$ & 3.86 & 0.702 & 13.400 & $<0.001$ \\
\hline ASS_2 : I feel safe in my transaction with the bank & 4.05 & 0.732 & 15.721 & $<0.001$ \\
\hline $\begin{array}{l}\text { ASS_3 : Employees in the bank are consistently } \\
\text { courteous with you }\end{array}$ & 3.78 & 0.654 & 12.978 & $<0.001$ \\
\hline $\begin{array}{l}\text { ASS_4 : Employees in the bank have knowledge to } \\
\text { answer your transaction }\end{array}$ & 3.63 & 0.685 & 10.126 & $<0.001$ \\
\hline
\end{tabular}

TABLE VIII Shows The EmPathy Dimension OF SERVICE Quality

\begin{tabular}{|l|c|c|c|c|}
\hline \multicolumn{1}{|c|}{ EMP : Empathy } & Mean & Std. Deviation & T value & P value \\
\hline $\begin{array}{l}\text { EMP_1 : The bank gives you individual } \\
\text { attention }\end{array}$ & 3.76 & 0.860 & 9.661 & $<0.001$ \\
\hline $\begin{array}{l}\text { EMP_2 : The bank has operating house convenient } \\
\text { to all its customers }\end{array}$ & 3.70 & 0.856 & 8.958 & $<0.001$ \\
\hline $\begin{array}{l}\text { EMP_3 : The has employees who give you } \\
\text { personal attention }\end{array}$ & 3.72 & 0.881 & 8.911 & $<0.001$ \\
\hline $\begin{array}{l}\text { EMP_4 : The bank has your best interest } \\
\text { at heart }\end{array}$ & 3.75 & 0.713 & 11.523 & $<0.001$ \\
\hline $\begin{array}{l}\text { EMP_5 : The employees of bank understand } \\
\text { your specific needs }\end{array}$ & 3.75 & 0.713 & 11.523 & $<0.001$ \\
\hline
\end{tabular}

\section{CONCLUSION}

With the recognition of service quality as an important avenue for development, during the last few years, scope and significance of service quality has been considerably widened while largely it strike remains a key tool for enhancing customer satisfaction and retention its value is being increasingly acknowledged. The advanced economies and advancing economies of the world are now dominated by services, and virtually all companies view service as critical to retaining their customers today and in future. The expectations of customers are on the increase especially customers who belong to young generation. Hence banks have to revise their traditional practices and adapt themselves to satisfy the needs of young customers. Employees need to be trained in such way that individual attention must to be provided to customers. The top management must invest considerable part of time and other resources to ensure the development of employee. The quality of service delivery results in customer satisfaction and their retention as it reinforces the perception that the value of the service received is greater than the price paid for it. As per the study there is not much gap between all the dimensions, this shows that SIB bank is a better service provider in all the dimensions.

\section{REFERENCES}

[1] Avkiran, K, N. (1994). Developing an instrument to measure customer service quality in branch banking. The International Journal of Bank Marketing, 12(6), 10-19.

[2] Caruana, Albert (2002), Service quality- The effects of service quality and the mediating role of customer satisfaction, European journal of marketing, 36(7/8)811-828.

[3] Johnston, R. (1997). Identifying the critical determinants of service quality in retail banking: importance and effects. The International Journal of Bank Marketing, 15(4), 111- 119.

[4] Jun, Minjoon.,Cai, Shaohan. (2001), (July). The Key Determinants Of Internet banking Service Quality: A Content Analysis. International Journal Of bank Marketing, 276-291.

[5] Parasuraman, A., Berry, L. L., and Zeithaml, V. A. (1988). SERVQUAL: A multiple item scale for measuring consumer perceptions of service quality. Journal of Retailing, 64(1), 12.

[6] Rust, R. T. \&Zahorik, A. J. (1993). Customer satisfaction, customer retention and market share. Journal of Retailing, 69(2), 193-215.

[7] Sureshchandar, G. S., Rajendran, C. and Anantharaman, R. N. (2002). The relationship between service quality and customer satisfaction-a factor specific approach, Journal of Services Marketing, 16, 363-379.

[8] Zeithaml, V. A. (2000). Service quality, profitability, and the economic worth of customers: what we know and what we need to learn, Journal of the Academy of Marketing Science, 28(1), 67-85. 